\title{
NEW SPECIES OF THE GENUS ERIOVIXIA ARCHER, 1951 (ARANEAE: ARANEIDAE) FROM BANGLADESH
}

\author{
Vivekanand Biswas* and Dinendra Raychaudhuri ${ }^{1}$ \\ Department of Zoology, Khulna Government Women's College, \\ Khulna-9000, Bangladesh
}

\begin{abstract}
A study on the orb-weaving spider genus Eriovixia Archer was carried out from different areas of Bangladesh. Two species of the genus were recorded of which one species E. nocturnalis nov. sp. is reported to be new to science and another one E. laglaizei (Simon) is a new record for the area of present study. The paper contains generic diagnosis, illustrated description, distribution and key to the species.
\end{abstract}

Key words: New species, Orb-weaving spider, Eriovixia, Araneae, Araneidae

\section{INTRODUCTION}

Orb-weaving spiders (family Araneidae) are one of the interesting group of arachnids well known to all due to their peculiar orb-weaving behaviour and geometric webs. Morphologically, these spiders are very attractive for their colour and decorated abdomen. Members of the genus Eriovixia Archer are typical and different among all araneids. These are nocturnal in behaviour and make large webs within the branches of trees at night.

Member of the genus Eriovixia are commonly known as 'fallen dry leave mimicking spiders' as they fall down on the ground from the webs and stay in the dry leaves throughout the day showing mimicry. The genus as first irrected by Archer in 1951 with the type-species Eriovixia rhinura (Pocock 1899). It contains 21 species worldwide (World Spider catalog 2017) of which 5 spiders in the Indian Sub-continent (Keswani et al. 2012, Ahmed et al. 2016) and only 1 (one) species in Bangladesh (Okuma et al. 1993, Biswas 2009). To date, the genus contains 15 species in other Asian countries viz. the Philippines (Barrion and Litsinger 1995), Japan (Tanikawa 1999, Tso and Tanikawa 2000), China (Han and Zhu 2010, Mi, et al. 2010, Mi and Wang 2016, Zhou et al. 2017, Zhu et al. 1994) and Singapore (Koh 1989).

Eriovixia is a small tropical orb-weavers. Berman and Levi (1971) treated the genus as a synonym of Neoscona Simon, 1864. Later Grasshoff (1986) removed it from Neoscona and treated it as a valid genus. The genus also resembles Eustala Simon 1895 in appearance with the presence of caudal elevation or appendage above and beyond the spinnerets.

*Author of correspondence: <vivekarach@gmail.com>. 1Entomology laboratory, Department of Zoology, University of Calcutta, 35, Ballygunge Circular Road, Kolkata-700019, India.

() 2018 Zoological Society of Bangladesh DOI: http://dx.doi.org/10.3329/bjz.v46i1.37621 
The present paper contains description of a new species E. nocturnalis nov. sp. together with report of an earlier described species E. laglaizei (Simon) from Bagerhat, Bangladesh.

\section{MATERIAL AND METHODS}

Collection and preservation: The specimens were collected from the gardens within and nearer to Govt. P.C. College campus, Bagerhat by vial tapping from the webs and by hand from the fallen dry leaves, respectively. All the collections were made early in the morning. Collected specimens were anesthesized with chlorform in a killing jar and then carried to the laboratory and immediately transferred them to a Petri dish filled with $70 \%$ ethyl alcohol for sorting. Thus, the specimens were kept for 2 - 3 hours for relaxation of body muscles (Chowdhury and Nagari 1981). The specimens were then preserved temporarily in $70 \%$ alcohol (single specimen in single vial) for further study.

After study, all the specimens were preserved permanently in 'Audmans preservative' (90 parts 70\% alcohol +5 parts glycerine +5 parts acitic acid). Preservation and other necessary techniques were followed by Tikader (1987).

Identification: Identification up to species level and a detailed taxonomic study of specimens was done based on various fauna volumes and relevant literatures of the world. The identity of the species was later confirmed from the Zoological Survey of India, Kolkata.

Illustrations: Illustrations, photographs and other necessary works were done by Camera lucida and Camera with macro lens fitted with stereo binocular microscope. Measurements of body parts and legs were taken in millimeters $(\mathrm{mm})$ with microscopic observations.

Type-deposition: Types of this study are at present in the collection of the Department of Zoology, Khulna Govt. Women's College and will be preserved at the Museum of the Department of Zoology, University of Dhaka, in due course of time.

\section{RESULTS AND DISCUSSION}

Family : Araneidae Latreille, 1804

Genus : Eriovixia Archer, 1951

Type : E. rhinura (Pocock, 1899)

1951. Eriovixia Archer, Amer. Mus. Novit., 1487 : 18.

1971. Neoscona: Berman and Levi, Bull. Mus. Comp. Zool. Harv. 141: 465.

1981. Neoscona : Tikader and Bal, Rec. Zool. Surv. India, Occ. pap. 24: 1.

1986. Eriovixia : Grasshoff, Ann. Zool. Wetenschappen 250: 118.

1989. Eriovixia : Koh, A guide to Singapor spiders: 36. 
1995. Eriovixia : Barrion and Litsinger, Riceland spiders of South and SE Asia: 640.

1997. Eriovixia : Platnick, Advances in Spideer Taxonomy : 500.

1997. Eriovixia : Yin et al., Fauna Sinica, Araneidae: 294.

1999. Eriovixia : Tanikawa, Acta Arachnol. 48: 41.

2010. Eriovixia : Mi et al., Zootaza 2488: 39.

2012. Eriovixia : Keswani, Indian J. Arachnol. 1(1) : 14.

2013. Neoscona : Biwas \& Raychaudhuri, Rec. Zool. Surv. India 113 (2): 169.

2014. Eriovixia : Raychaudhuri \& Saha, Atlas Insects \& Spiders of BTR: 1.

2016. Eriovixia : Ahmed et al., Indian J. Arachnol. 5: 24.

2017. Eriovixia : World Spider Catalog, Version 17.O, Nat. Hist. Mus. Bern (accessed on 07.08.2017).

Diagnosis: Members of the genus Eriovixia Archer are dark in colour with decorated abdomen. Body elongately oval, with wider abdomen. Carapace pilose specially the cephalic area. Anterior row of eyes straight; posteromedian eyes slightly larger than the anterior ones; cephalic region with distinct fovea. Abdomen sub-triangular, with or without caudal appendage, abdominal tip elongate, protruded. Legs slender, tibia I longer than carapace. Female larger; epigunum bears a stout scape with recurved tip, flatter than those in Neoceona. Tibia of male pedipalps with two long setae and median apophysis projecting apically.

Biological note: Members of the genus Eriovixia are tropical nocturnal orbweavers. They spain a typical geometric webs at night in which stay in the middle vertically. If they distdurbed, immediately fall down on the ground and make place within fallen dry leaves throughout the day. It shows mimicry with the leaves that they cannot identify. So, they are called 'fallen dry leave mimicking spiders.'

They are good predators of insect pests of garden and forests. They consume numerous insects per day by the webs made by them and so that they are one of the good biological control agents of pest insects of field crops.

Distribution: Southeast Asia to Africa.

\section{Key to the species}

1. Cephalothorax with distinct cervical furrows and rounded fovea; abdominal dorsum decorated upto long caudal projection; inner margin of chelicerae with 3 strong teeth (Fig. 1b); anterior margin of sternum nearly straight (Fig. 1d); epigynum and internal genitalia as in Figs le-f 
- Cephalothorax without cervical furrows and with elongate fovea; abdominal dorsum not decorated; inner margin of chelicerae with 2 pointed teeth (Fig. 2b); anterior margin of sternum strongly concave (Fig. 2d); epigynum and internal genitalia as in Figs. 2e-f

nocturnalis nov. sp.

\section{Eriovixia laglaizei (Simon)}

(Figs. 1a-f)

1877. Epeira laglaizei Simon, Ann. Soc. Ent. Fr. 7(5): 77.

1900. Araneus laglaizei : Pocock, Fauna of Brit, India, Arachn.: 224.

1971. Neoscona laglaizei: Berman and Levi, Mus. Comp. Zool. Harv. 141: 465.

1981. Neoscona laglaizei: Tikader and Bal, Rec. Zool. Surv. India, Occ. pap. 24: 27.

1986. Eriovixia laglaizei : Grasshoff, Zool. Wetensch 250: 118.

1994. Neoscona laglaizei: Zhu et al., J. Hevei norm Univ : 25.

1995. Eriovixia laglaizei : Barrion and Litsinger, Riceland spiders of South and SE Asia: 641.

1997. Eriovixia laglaizei : Yin et al. Fauna Sinica, Arachrida, Araneidae: 298.

1997. Eriovixia laglaizei : Platnick, Advances in Spider Taxonomy: 500

1999. Eriovixia laglaizei : Song et al. The Spiders of China: 287

1999. Eriovixia laglaizei : Tanikawa. Acta Arachnol. 48: 41.

2010. Eriovixia laglaizei : Han \& Zhu, J. Nat. Hist. 44: 2609.

2010. Eriovixia laglaizei : Mi et al. Zootaxa 2488: 39.

2012. Eriovixia laglaizei : Keswani et al. Indian J Arachnol. 1(1): 14.

2013. Neoscona laglaizei: Biswas and Raychaudhuri, Rec. Zool. Surv. India, 113(2): 173.

2014. Eriovixia laglaizei : Raychaudhuri and Saha, Atlas of insects and spiders of BTR: 38.

2017. Eriovixia laglaizei : Zhau et al., Acta Arach. Sinica 26(1): 6.

2017. Eriovixia laglaizei : World Spider Catalog, Version 17.0 Nat. Hist. Mus. Bern, (accessed on 07.08.2017).

Material examined: 1ㅇ, Chitalmari, Bagerhat, 18.V.1993, Coll. V. Biswas; 2 , Jessore, 25.IX. 1993, Coll. V. Biswas; 19, Kustia, 18 IV. 1994, Coll. V. Biswas; 19, Faridpur, 12.V.1994; Coll. V. Biswas.

General: Cephalothorax yellowish, legs yellowish black; abdomen greyish yellow. Total body length $8.50 \mathrm{~mm}$. Carapace $3.10 \mathrm{~mm}$ long, $2.60 \mathrm{~mm}$ wide; abdomen $6.20 \mathrm{~mm}$ long and $4.85 \mathrm{~mm}$ wide.

Distribution: Bangladesh: Bagerhat, Jessore, Kushtia and Faridpur, India; China, Myanmar, Japan, Africa (Tikader and Bal 1981, Han and Zhu 2010, Yin et al. 1997, Tanikawa 1999, Barrion and Litsinger 1995, Raychaudhuri and Saha 2014). 

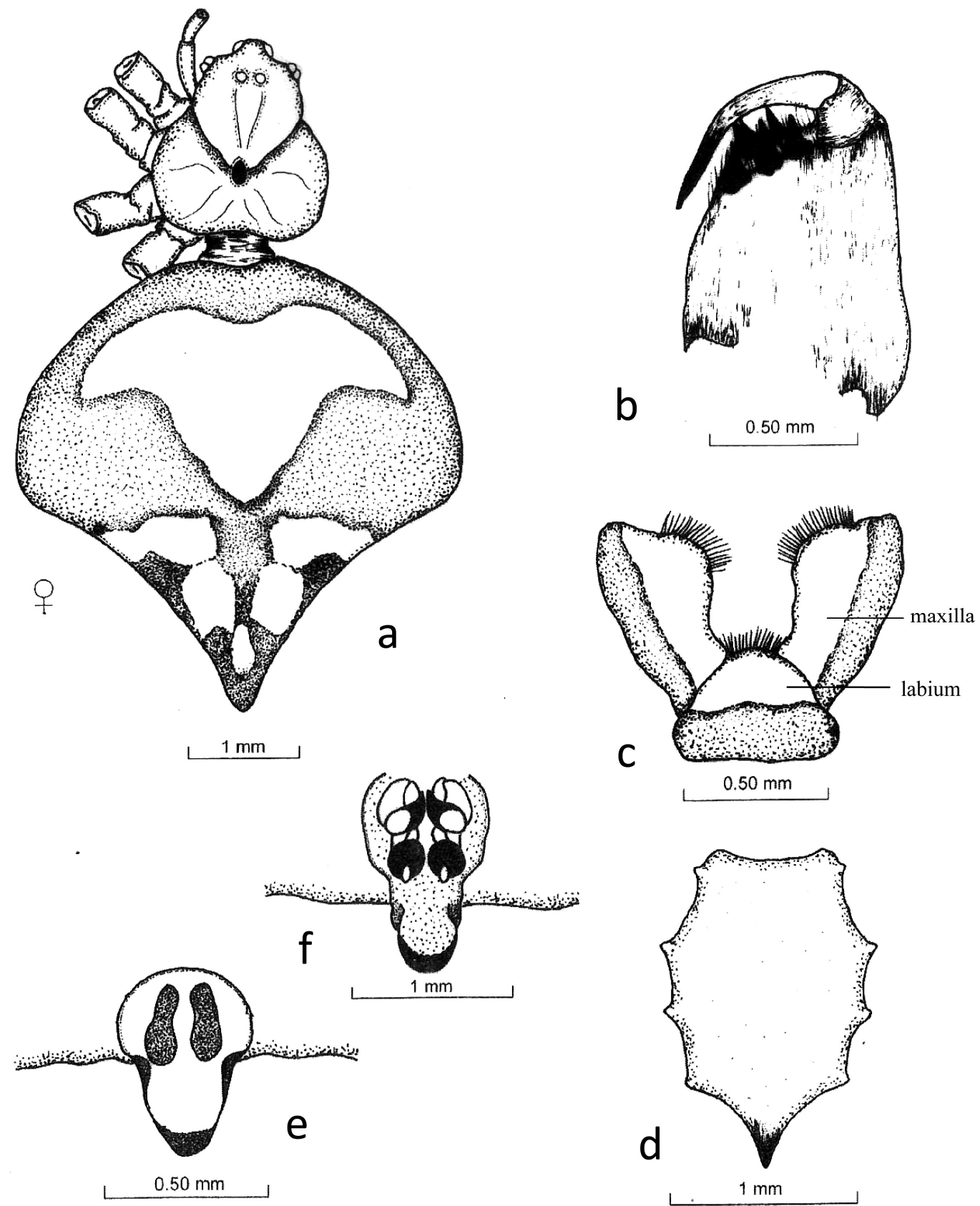

Fig. 1a-f. Eriovixia laglaizei (Simon). a. Whole body (dorsal view), b. Chelicerae, c. Maxillae and Labium, d. Sternum, e. Epigynum, f. Internal genitalia. 
Material examined: Holotype : 19, Chitalmari, Dist. Bagerhat, 18.IX. 1993; Coll V. Biswas.

Paratypes: 2 , otherwise data same as for the holotype. 19 , Pirojpur, 12.X. 1993. Coll. V. Biswas.

General: Cephalothorax, legs and abdomen light brown; Total body length (holotype) $18.00 \mathrm{~mm}$. Carapace $6.20 \mathrm{~mm}$ long, $5.50 \mathrm{~mm}$ wide; abdomen 11.80 $\mathrm{mm}$ long and $10.90 \mathrm{~mm}$ wide.

Cephalothorax: Longer than wide, posteromedially broad, medially with a conspecuous long fovea, laterally decorated with blackish markings. Eyes pearly white, dissimilar, arranged in 2 rows; both rows of eyes recurved; lateral eyes close, placed marginally; anteromedians situated on the anteriorly narrowed cephalic region; ocular quad slightly wider anteriorly and narrowing posteriorly; both anterior and posterior row of eyes procurved (Fig. 2a). Chelicerae brown, long, parallel sided, strong, each of inner and outer margins with 2 and 4 teeth (Fig. 2b). Maxillae brown, longer than wide, wider anteromedially, scopulate anteriorly (Fig. 2c). Labium blackish brown, wider than long, pot-like, scopulate anteriorily (Fig. 2c). Sternum brown, longer than wide, wide anteriorly and narrowed posteriorly and bluntly pointed, anterior margin strongly concave (Fig. 2d). Legs long, clothed with spines and hairs; leg formula 1423 and the measurements $(\mathrm{mm})$ as shown in Table 1 .

Male pedipalp light brown with all segments slender, longer than tarsus and metatarsus; presence of numerous setae all over the segments except trochanter and femur where less or a few number of setae present.

Abdomen: broad, dark brown, rhomboid, medially wide, poseriorly abruptly narrowed to form an elongate blunt projection, clothed with fine hairs; Ventrally light brown in colour from anterior upto the spinnerets. Dorsum without any hairs or spines.

Spinneret slightly away from the tip of abdomen, light brown, segmented, tip slightly curved and aggregated together, clothed with small hairs. Epigyne long, brown, tongue-like (Fig. 2e), directed forward; epigastric furrow curved; internal genitalic nearly vase-shaped, with enlarge base, copulatory ducts ' $C$ ' shaped (Fig. 2f).

Type-locality: Gardens of Bagerhat and Pirojpur districts, Bangladesh, from the webs made by them.

Etymology: The species is named because of its nocturnal habit. 


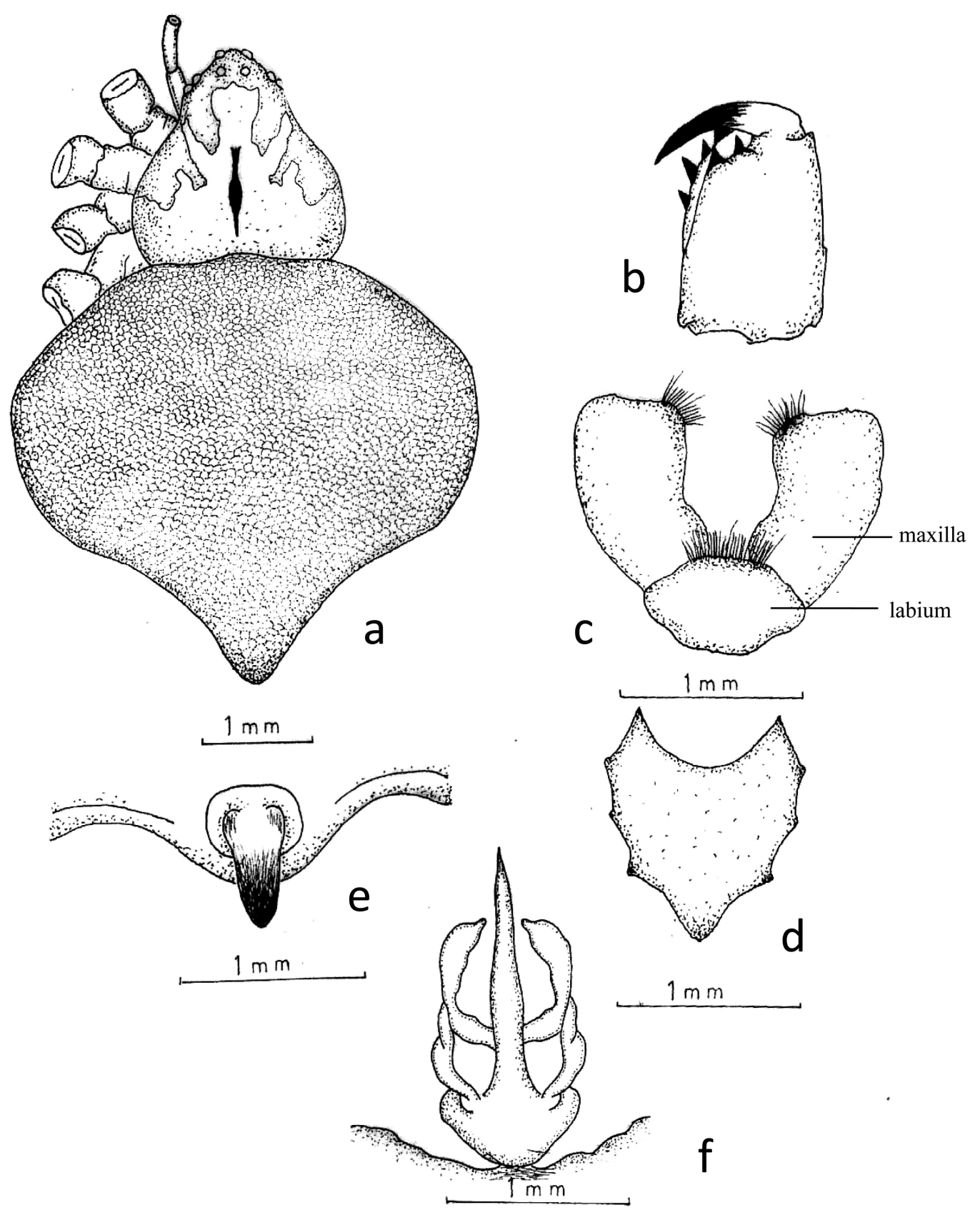

Figs 2a-f: Eriovixia nocturnalis nov. sp. a. Whole body (dorsal view), b. Chelicerae, c. Maxillae and Labium, d. Sternum, e. Epigynum, f. Internal genitalia. 
Diagnosis: The new species Eriovixia nocturnalis nov. sp. appears close to E. laglaizeii (Simon) (Biswas and Raychaudhury 2013) in having rhomboid abdomen. Contension of proposing it as a new species in because of the district different characters with above indicated one in the following:

1. Cephalic region anteriorly narrowed.

2. Cervical furrows absent.

3. Elongate forea.

4. Abdomen entirely reticulate, anterior margin nearly straight, lateral hump absent.

5. Inner margin of chelicerae with 2 teeth.

6. Epigynal scape tongue-like, pointed and internal genitalia vase-shaped (Figs 2e-f).

Therefore, the species is described as new to science.

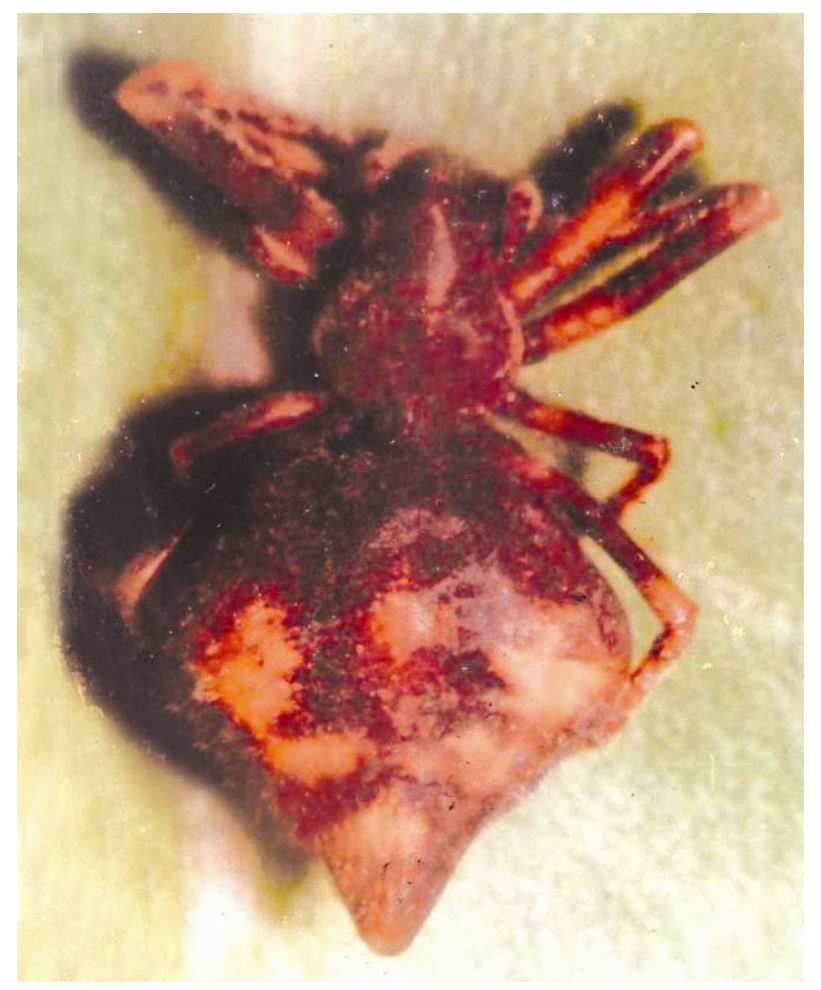

Fig. 3. Eriovixia nocturnalis nov. sp. 
Table 1. Measurements (mm) of leg segments of Eriovixia nocturnalis nov. sp.

\begin{tabular}{ccccccc}
\hline Leg & $\begin{array}{c}\text { Femur } \\
(\mathrm{mm})\end{array}$ & $\begin{array}{c}\text { Petella } \\
(\mathrm{mm})\end{array}$ & $\begin{array}{c}\text { Tibia } \\
(\mathrm{mm})\end{array}$ & $\begin{array}{c}\text { Metatarsus } \\
(\mathrm{mm})\end{array}$ & $\begin{array}{c}\text { Tarsus } \\
(\mathrm{mm})\end{array}$ & $\begin{array}{c}\text { Total } \\
(\mathrm{mm})\end{array}$ \\
\hline I & 4.50 & 1.00 & 2.50 & 1.50 & 0.90 & 10.40 \\
II & 3.00 & 1.00 & 1.50 & 1.20 & 0.50 & 7.20 \\
III & 0.90 & 0.20 & 0.80 & 0.70 & 0.30 & 2.90 \\
IV & 3.00 & 1.20 & 1.50 & 1.40 & 0.60 & 7.70 \\
\hline
\end{tabular}

Members of the genus Eriovixia are tropical, nocturnal orb-weavers occuring mainly on the webs vertically. Spiders of this genus are inhabiting in the garden and forests of Bangladesh. In Indian sub-continent, the genus was first reported by Pocock (1900) as Araneus laglaizei and till date, only 5 species are recorded in India and only one species in Bangladesh (Biswas 2009, World spider catalog 2017). The present study added a new species with another earlier recorded one in a different locality of the country. As the country is rich in forest flora and fauna, so as a forest species their number must increase in future study and will help in identification and conservation practices of the endangered spider species of the country.

In the present description, both the species are typical in their characters and identity as stated in the text. Also, they differ in some natural colour and other morphological characters with the members described in the neighbouring countries. Therefore, these are very important taxonomically.

Eriovixia species are fallen dry leave mimicking spiders. They stay at the day in fallen dry rolled leaves dropping from the webs from where they consume small insects. Thus, they play a great role in the management of garden and forest insect pests.

Acknowledgements: The authors are grateful to Dr. S.C. Majumder, ScientistSD, Zoological Survey of India, Kolkata, for kind help in confirmation of the identity of the species and the Head, Department of Zoology, University of Kolcutta, for kind permission during the course of this study.

\section{LITERATURE CITED}

AHMED, J. KHALAP, R. and SUMUKHA, J.N. 2016. A new species of dry foliage mimicking Eviovixia Archer, 1951 from central western ghats, India (Araneae : Araneidae). Indian J. Arachnol. 5: 2427.

BARRION, A.T. and LITSINGER, J.A. 1995. Riceland spiders of South and Southeast Asia. CAB International, Wellington, 700p.

BERMAN, J.D. and LEVI, H.W. 1971. The orb-weaver genus Neoscona in North America. Bull. Mus. Comp. Zool. Harv. 141: 465-500. 
BISWAS, V. 2009. (In Ahmed ed.) Encyclopedia of flora and fauna of Bangladesh, Arachnida, 18(1), Asiatic Society of Bangladesh, Dhaka, 437 p.

BISWAS, V. and RAYCHAUDHURI, D. 2013. Orb-weaving spiders of Bangladesh: Genus Neoscona Simon (Araneae : Araneidae). Rec. Zool. Surv. India 113(2): 169-188.

CHOWDHURY, S.H. and NAGARI, S. 1981. Rice-field spiders of Chittagong. Proc. Zool. Soc. Bangladesh : 53-71.

GRASSHOFF, M. 1986. Die Radnetzspinnen - Gattung Neoscona in Africa (Arachnida : Araneae). Ann. Zool. Wetenschappen 250: 1-123.

HAN, G.X. and ZHU, M.S. 2010. Taxonomy and biogeography of the spider genus Eriovixia (Araneae : Araneidae) from Hainan Island, China. J. Nat. Hist. 44: 2609-2635.

KESWANI, S. HADOLE, P. and RAJORIA, A. 2012. Checklist of spiders (Arachnida : Araneae) from India. Indian J. Arachnol. 1(1): 1-129.

KOH, J.K.H. 1989. A guide to Singapore Spiders. Singapore Science Centre, 160 p.

MI, X.Q. and WANG, C. 2016. First description on the female of Eriovixia huwena and the male of $E$. poonaensis (Araneae : Araneidae). Sichuan J. Zool. 35(5): 728-733.

MI, X.Q., PENG, X.J. and YIN, C.M. 2010. The orb-weaving spider genus Eviovixia (Araneidae) in the Gaoligong mountains, China, Zootaxa 2488: 39-51.

OKUMA. C., KAMAL, N.Q. HIRASDHIMA, Y., ALAM, Z. and OGATA, T. 1993. Illustrated Monograph of the rice-field spiders of Bangladesh. IPSA-JICA, Gazipur, $93 \mathrm{p}$.

PLATNICK, N.I 1997. Advances in Spider Taxonomy. American Museum of Natural History, New York, $630 \mathrm{p}$.

POCOCK, R.I. 1899. Diagnoses of some new Indian Arachnida. J. Bombay Nat. Hist. Soc. 12: 744753.

POCOCK, R.I. 1900. The Fauna of British India, Arachnida. Today \& Tomorows Printers \& Publishers, New Delhi, 279 p.

RAYCHAUDHURI, D. and SAHA, S. 2014. Atlas of Insects and Spiders of Buxa Tiger Reserve. West Bengal Biodiversity Board and NBI, Kolkata, 357 p.

SONG, D.X., ZHU, M.S. and CHEN, J. 1999. The spiders of China. Hebei Sci. and Tech. Pub. House. 640 p. +4 plates.

TANIKAWA, A. 1999. Japanese Spiders of the genus Eriovixia (Araneae : Araneida). Acta Arachnol. Tokyo 48: 41-48.

TIKADER, 1987. Handbook of Indian Spiders. Director, Zoological Survey of India, Kolkata, 287p.

TIKADER, B.K. and BAL, A. 1981. Studies on some orb-weaving spiders of the genus Neoscona Simon and Araneus Clerck of the family Araneidae (=Argiopidae) from India. Rec. Zool. Surv. India. Occ. pap. No. 24: 1-60.

TSO, I.M. and TANIKAWA, A. 2000. New records of five orb-web spiders of the genus Leucauge, Mesida and Eriovixia (Aranea : Tetragnathidae \& Araneidae) of Taiwan. Acta Arachnol. 49: 125131.

WORLD SPIDER CATALOG, 2017. World Spider Catalog. version 17.0, Natural History Museum, Bern (accessed on 07.08.2017).

YIN, C.M. WANG, J. ZHU. M.S., XIE, L.P., PENG, X.J. and BAO, Y. 1997. Fauna Sinica, Arachnida (Aranae : Araneidae). Science Press, Beijing, 460 p.

ZHOU, H. ZHU, J. and ZHANG, Z.S. 2017. Two new and four newly recorded species of orb-weaver spiders from China (Araneae : Araneidae). Acta Arach. Sin. 26(1): 6-12.

ZHU, MS, SONG, DX, Zhang, Y.Q. and Wang. X.P. 1994. On some new species and new records of spiders of the family Araneidae from China. J. Hebei norm. Univ. (Nat. Sci. ed.). 12: 25-52.

(Manuscript received on 2 October, 2017; revised on 25 May, 2018) 